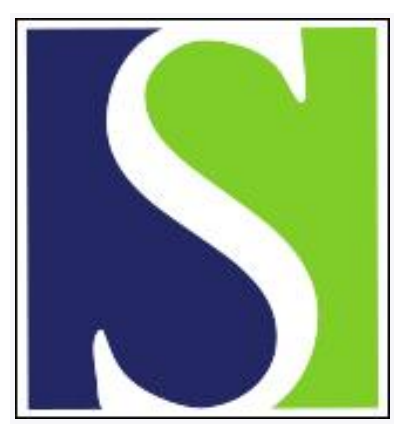

Scand J Work Environ Health 1989;15(6):404-414

https://doi.org/10.5271/sjweh.1832

Issue date: Dec 1989

Physical work load, fetal development and course of pregnancy.

by Nurminen T, Lusa S, Ilmarinen J, Kurppa K

Affiliation: Institute of Occupational Health, Helsinki, Finland.

The following articles refer to this text: 2013;39(1):88-95;

2013;39(4):335-342

This article in PubMed: www.ncbi.nlm.nih.gov/pubmed/2617257

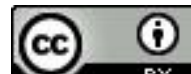




\title{
Physical work load, fetal development and course of pregnancy
}

\author{
by Tuula Nurminen, MSc, Sirpa Lusa, MSc, Juhani IImarinen, PhD, Kari Kurppa, MD ${ }^{1}$
}

\begin{abstract}
NURMINEN T, LUSA S, ILMARINEN J, KURPPA K. Physical work load, fetal development and course of pregnancy. Scand J Work Environ Health 1989;15:404-414. The effects of physical work load during pregnancy were analyzed in connection with a nationwide case-referent study that screened for associations between selected structural malformations and occupational exposures. The strain of the occupational activities of 1475 mothers of malformed infants and an equal number of mothers of noncase babies was assessed from a description of the work tasks by an expert using a standardized method reflecting energy expenditure. The noncase mothers' experience revealed a relation between physical load and growth retardation that has also been suggested by other epidemiologic studies. No relation was found between an increase in mean physical load and the occurrence of threatened abortion; yet work involving much standing had an increased risk. Mothers whose work included occasional high physical loads had more pregnancy-induced hypertension. The data showed unexpected associations between physical load and structural malformations.
\end{abstract}

Key terms: birth defects, birthweight, energy expenditure, length of gestation, malformations, occupation, pregnancy-induced hypertension, threatened abortion, vaginal bleeding.

Rather little is known about the effects of a mother's physical work load on the fetus and the course of pregnancy. Exercise during pregnancy has been described to result in a reduction of birthweight in some animal studies, but not in all, and some epidemiologic studies have shown an association between low birthweight and physically demanding work (1). A recently published study reported that the occupational lifting of heavy weights retarded fetal growth (2). The evidence from studies on spontaneous abortion and ergonomic factors suggests that heavy lifting and physical effort may be associated with an increased risk for this occurrence $(3,4)$. There are results $(5)$ suggesting that voluntary, moderate physical exercise during pregnancy may actually protect against preterm delivery, whereas heavy physical effort during work and strenuous work conditions may carry a risk of preterm birth (4).

The occurrence of human birth defects in relation to physical work demands has not been explored to any great extent, except in studies which have categorized women according to occupational titles. An investigation in Montreal (6) analyzed subgroups of structural birth defects in relation to work, but the report did not include results related to physical work load and structural congenital malformations. Instead, these data showed an association between positional musculoskeletal defects and a long work week but no relation to ergonomic factors.

As a part of a case-referent study screening for associations between selected structural birth defects and

\footnotetext{
1 Institute of Occupational Health, Helsinki, Finland.
}

Reprint requests to: Ms T Nurminen, Department of Epidemiology and Biostatistics, Institute of Occupational Health, Topeliuksenkatu 41 a A, SF-00250 Helsinki, Finland. occupational exposures on a nationwide basis $(7,8)$, the present report describes the results concerning physical work load during pregnancy. To study threatened abortion, pregnancy-induced hypertension, length of gestation, and birthweight, we analyzed the information obtained on the noncase mothers. Special emphasis was placed on exposure evaluation, and physical work load was assessed from a description of the mother's work tasks by an expert who used a standardized method reflecting energy expenditure.

\section{Subjects and methods}

\section{Birth defects}

The source data of the study, obtained from the Finnish Register of Congenital Malformations, included 365 defects of the central nervous system, 581 orofacial clefts, 360 structural defects of the skeleton, 169 cardiovascular malformations, and 1475 noncase babies whose deliveries had preceded the case deliveries in the same maternity health care district $(8,9)$. The notifications and autopsy reports of the case babies were checked by a trained pathologist of the Register, and infants with known chromosome anomalies were not included. The mothers of the case and noncase babies were interviewed by means of standard Register procedures about particulars of the latest and previous pregnancies, diseases, intake of drugs and alcohol, smoking, etc. About $99 \%$ of the interviews were successful (10).

Information on the mothers' work conditions was acquired through special interviews performed by two trained interviewers from the Finnish Institute of Occupational Health $(8,9,11)$. The interviews took place about two to four months after the delivery. During 
the interviewer's visit to the maternity health care center both mothers of the case-noncase pair were usually interviewed. Interviews were completed for $96 \%$ of the pairs of mothers with eligible infants (9).

In all, 2073 mothers had worked throughout most of their pregnancy, 274 mothers had worked only temporarily, and 603 mothers had not worked in the first trimester. When birth defects were considered, the analyses were restricted to mothers who had worked in the first trimester of pregnancy.

The physical load of the mother's occupational activities was assessed from a description of her ordinary workday, which had been recorded in detail in the special interview. The evaluation was based on a standardized method reflecting energy expenditure (12). Table 1 shows the applied standardized activity categories (13). An expert in physical education, trained at the Department of Physiology of the Finnish Institute of Occupational Health, assessed the mother's major activity level at work. If the work included clear changes in physical load, the minor activity level was also assessed. Occasional loads that exceeded the major and minor levels were evaluated separately. (See table 2.) The assessment was done by the trimesters of pregnancy without the evaluator knowing the events related to the course of gestation or the pregnancy outcome.

Groups representing short-term physical load were defined according to the physically most strenuous level that had occurred in the work as a main or minor level, or as an occasional load. In the first trimester the work of 1078 mothers had included only light activities (categories 3-5 in tables 1 and 2), 707 mothers had worked in jobs with a moderate physical load (category 6 in table 2), and 516 mothers had had some tasks that entailed a high physical load (categories 7 and 8 in table 2).

The mother's mean level of physical load was calculated as an average of the major and minor levels weighted by the proportion of worktime spent at the level concerned. For example, an office clerk who had been sitting and writing $80 \%$ of her worktime and had been standing and taking photocopies $20 \%$ of the time was given a score of $3.2(0.8 \times 3+0.2 \times 4)$. Occasional loads were not included when the mean level of the physical load was calculated.

The mothers were categorized according to the weighted activity score into groups representing (i)

Table 1. Classification of some of the mothers' occupational tasks into the standardized activity categories.

\begin{tabular}{|c|c|c|c|}
\hline Score & Standardized activity category ${ }^{a}$ & $\begin{array}{c}\text { Metabolic } \\
\text { reference } \\
\text { value }^{b}\end{array}$ & Occupational task \\
\hline 3 & Sitting without special movements & 1.5 & Sitting and writing, control on night duty, driving a car \\
\hline 4 & Standing with very light movements & 3.0 & $\begin{array}{l}\text { Arranging documents, teaching or supervising, } \\
\text { feeding a patient, cleaning instruments }\end{array}$ \\
\hline 5 & Walking or physically light activities & 4.0 & $\begin{array}{l}\text { Lifting and carrying burdens weighing }<5 \mathrm{~kg} \text {, making } \\
\text { a nursing round, arranging space to work }\end{array}$ \\
\hline 6 & $\begin{array}{l}\text { Activities with a moderate } \\
\text { physical load }\end{array}$ & 5.0 & $\begin{array}{l}\text { Lifting and carrying burdens weighing between } 5 \text { and } \\
10 \mathrm{~kg} \text {, making beds, sweeping and vacuuming }\end{array}$ \\
\hline 7 & Activities with a high physical load & 8.0 & $\begin{array}{l}\text { Lifting and carrying burdens weighing between } 10 \text { and } \\
25 \mathrm{~kg} \text {, moving a patient together with another person }\end{array}$ \\
\hline 8 & $\begin{array}{l}\text { Activities with a very high } \\
\text { physical load }\end{array}$ & 10.0 & $\begin{array}{l}\text { Lifting and carrying burdens weighing } \geq 25 \mathrm{~kg} \text {, moving } \\
\text { a patient alone }\end{array}$ \\
\hline
\end{tabular}

a Category 1 , lying asleep, and category 2 , Iying awake, were not applicable.

$b$ The energy expenditure is around 1.5 times the basal metabolic rate, etc.

Table 2. Activity levels and occasional loads in the first trimester of pregnancy among the mothers who worked.

\begin{tabular}{|c|c|c|c|c|c|c|c|}
\hline \multirow{2}{*}{\multicolumn{2}{|c|}{$\begin{array}{l}\text { Standardized } \\
\text { activity } \\
\text { category }\end{array}$}} & \multicolumn{2}{|c|}{$\begin{array}{c}\text { Major } \\
\text { activity level }\end{array}$} & \multicolumn{2}{|c|}{$\begin{array}{c}\text { Minor } \\
\text { activity level }\end{array}$} & \multicolumn{2}{|c|}{$\begin{array}{l}\text { Occasional } \\
\text { loads }^{\mathrm{a}}\end{array}$} \\
\hline & & \multirow{2}{*}{$\frac{\mathrm{N}^{\mathrm{b}}}{1049}$} & \multirow{2}{*}{$\begin{array}{c}\% \\
45.5\end{array}$} & \multirow{2}{*}{$\frac{\mathrm{N}^{\mathrm{c}}}{254}$} & \multirow{2}{*}{$\frac{\%}{11.0}$} & \multirow{2}{*}{$\mathrm{N}$} & \multirow{2}{*}{$\%$} \\
\hline 3 & (sitting without special movements) & & & & & & \\
\hline 4 & (standing with very light movements) & 752 & 32.7 & 416 & 18.1 & 22 & 1.0 \\
\hline 5 & (walking or physically light activities) & 49 & 2.1 & 255 & 11.1 & 82 & 3.6 \\
\hline 6 & (activities with a moderate physical load) & 446 & 19.4 & 346 & 15.0 & 218 & 9.5 \\
\hline 7 & (activities with a high physical load) & 6 & 0.3 & 55 & 2.4 & 439 & 19.0 \\
\hline 8 & (activities with a very high physical load) & 1 & 0.0 & 2 & 0.0 & 19 & 0.8 \\
\hline \multicolumn{2}{|c|}{ Total } & 2303 & 100 & 1328 & 57.6 & 780 & 33.9 \\
\hline
\end{tabular}

a The total duration of the loads was less than $10 \%$ of the total worktime.

b There were 44 mothers for whom the physical work load could not be assessed.

c A total of 973 mothers worked at the same activity level all the time, and for two mothers the distribution of worktime between the different activity levels could not be defined. 
sedentary work $(3 \leq$ weighted score $<4)$, (ii) standing work $(4 \leq$ weighted score $<5$ ), (iii) work involving walking $(5 \leq$ weighted score $<6$ ), (iv) work with a moderate mean physical load $(6 \leq$ weighted score $<7)$, and (v) work with a high mean physical load (weighted score $\geq 7$ ). There were only two mothers whose mean physical load in the first trimester had been high. These two women were included in the moderate group. In all, 1241 mothers belonged to the first category, 574 to the second, 187 to the third, and 299 to the fourth.

Office clerk, keyboard operator, sewer, and production-line worker are examples of occupations categorized as sedentary work. Job titles such as shop assistant, cook, and baker typically represented standing work. Nurse's aids, domestic aids, and waitresses usually did much walking. Agricultural workers, cleaners, and packers, but also some waitresses and production-line workers, had a moderate mean physical load. Of the two mothers with a high mean physical work load one was a plywood-fiberboard worker and the other a forestry worker.

In the analyses the levels of the group means and short-term physical loads were used as nominal activity categories. Table 3 shows the mothers according to these categories.

Most of the mothers with a moderate mean physical load were manual workers when classed on a socioeconomic basis (14) (table 4). Moreover, the groups representing distinct mean physical loads differed with respect to other work characteristics. For example, almost all of the mothers in agricultural work belonged to the group with a moderate mean load (table 5). In addition to studying all the mothers who worked in the first trimester, we restricted some analyses to nonagricultural workers in the two socioeconomic classes of lower-level employees with administrative and clerical occupations and manual workers while adjusting for shift work, exposure to noise and solvents, a long work week, temporariness of employment; and mother's belonging to either of the two socioeconomic classes.

The group with a moderate mean physical load included more older mothers, fewer mothers without a previous pregnancy, and fewer mothers who had consumed alcohol during pregnancy (table 6). When we studied the relation between physical work load and malformations, we adjusted for the aforementioned work characteristics and also for maternal age of $\geq 35$ years, birth order higher than three, two or more induced abortions, previous miscarriage, previous malformed child, previous stillbirth, regular smoking, alcohol consumption, intake of drugs in the first trimester, and common cold or fever in the first trimester.

The matching procedure had correlated the case and noncase series with respect to agricultural work, and, as a consequence, with respect to physical work load. When all the mothers who worked during early pregnancy were studied, the data were analyzed as matched

Table 3. Groups representing mean and short-term physical load in the first trimester of pregnancy.

\begin{tabular}{|c|c|c|c|c|c|c|}
\hline \multirow{3}{*}{$\begin{array}{l}\text { Mean } \\
\text { physical } \\
\text { load }^{\mathrm{a}}\end{array}$} & \multicolumn{6}{|c|}{ Short-term physical load } \\
\hline & \multicolumn{2}{|c|}{ Light } & \multicolumn{2}{|c|}{ Moderate } & \multicolumn{2}{|c|}{ High } \\
\hline & $N$ & $\%$ & $\mathrm{~N}$ & $\%$ & $\mathrm{~N}$ & $\%$ \\
\hline Sedentary work & 993 & 80.0 & 173 & 13.9 & 75 & 6.1 \\
\hline Standing work & 81 & 14.1 & 260 & 45.3 & 233 & 40.6 \\
\hline Work with walking & 4 & 2.1 & 88 & 47.1 & 95 & 50.8 \\
\hline Work with a moderate physical load & $\cdot$ & & 186 & 62.2 & 113 & 37.8 \\
\hline
\end{tabular}

a Short occasional loads not taken into account.

b Short occasional loads included.

Table 4. Mother's socioeconomic class and mean physical load in the first trimester of pregnancy.

\begin{tabular}{|c|c|c|c|c|c|}
\hline & ioeconomic class $^{a}$ & $\begin{array}{l}\text { Sedentary work } \\
\quad(\mathrm{N}=1241)\end{array}$ & $\begin{array}{l}\text { Standing work } \\
(\mathrm{N}=574)\end{array}$ & $\begin{array}{c}\text { Work involving } \\
\text { walking } \\
(\mathrm{N}=187)\end{array}$ & $\begin{array}{l}\text { Work with a } \\
\text { moderate } \\
\text { physical load }\end{array}$ \\
\hline 2 & Own-account workers ${ }^{b}$ & 0.5 & 1.2 & 1.1 & 1.0 \\
\hline 3 & $\begin{array}{l}\text { Upper-level employees with administrative, } \\
\text { managerial, professional and related occupations }\end{array}$ & 15.1 & 2.5 & 1.1 & 0.3 \\
\hline 4 & $\begin{array}{l}\text { Lower-level employees with administrative } \\
\text { and clerical occupations }\end{array}$ & 65.4 & 55.6 & 50.3 & 5.0 \\
\hline 5 & Manual workers & 14.4 & 38.3 & 42.2 & 92.0 \\
\hline 7 & Students ${ }^{c}$ & 4.6 & 2.4 & 5.3 & 1.7 \\
\hline To & & 100 & 100 & 100 & 100 \\
\hline
\end{tabular}

a According to reference 14 .

b Own-account $=$ self-employed

c Women in occupational training. 
Table 5. Work characteristics and mother's mean physical load in the first trimester of pregnancy.

\begin{tabular}{|c|c|c|c|c|}
\hline Work characteristic & $\begin{array}{l}\text { Sedentary work } \\
\qquad(\mathrm{N}=1241) \\
(\%)\end{array}$ & $\begin{array}{l}\text { Standing work } \\
\qquad(\mathrm{N}=574) \\
(\%)\end{array}$ & $\begin{array}{c}\text { Work involving } \\
\text { walking } \\
(\mathrm{N}=187) \\
(\%)\end{array}$ & $\begin{array}{c}\text { Work with a } \\
\text { moderate } \\
\text { physical load } \\
(\mathrm{N}=299) \\
(\%)\end{array}$ \\
\hline Temporary work & 8.5 & 12.9 & 13.4 & 15.7 \\
\hline Agricultural work & 0.2 & 0.2 & 3.7 & 51.2 \\
\hline Shift work & 10.2 & 22.8 & 43.3 & 8.7 \\
\hline Noise exposureb & 8.1 & 7.8 & 10.2 & 13.4 \\
\hline Solvent exposure & 3.7 & 2.6 & 2.1 & 6.7 \\
\hline Long work week ${ }^{d}$ & 4.7 & 14.6 & 9.2 & 17.8 \\
\hline
\end{tabular}

a Farm, commercial garden, park, and forestry work.

b Level of noise an 8-h equivalent continuous A-weighted sound level of around $80 \mathrm{~dB}$ or higher.

c Continuous concentrations of at least one-third of the threshold limit values for chemical substances in workroom air (15) or peaks higher than the threshold limit value.

d Weekly worktime $>40 \mathrm{~h}$.

Table 6. Maternal characteristics and mean physical load in the first trimester of pregnancy.

\begin{tabular}{|c|c|c|c|c|}
\hline Maternal characteristic & $\begin{array}{l}\text { Sedentary work } \\
\qquad(\mathrm{N}=1241) \\
(\%)\end{array}$ & $\begin{array}{l}\text { Standing work } \\
\qquad \begin{array}{c}(\mathrm{N}=574) \\
(\%)\end{array}\end{array}$ & $\begin{array}{l}\text { Work involving } \\
\text { walking } \\
(\mathrm{N}=187) \\
(\%)\end{array}$ & $\begin{array}{c}\text { Work with a } \\
\text { moderate } \\
\text { physical load } \\
(\mathrm{N}=299) \\
(\%)\end{array}$ \\
\hline Maternal age $\geq 35$ years & 8.2 & 4.7 & 10.2 & 15.4 \\
\hline No previous pregnancy & 41.0 & 41.6 & 37.6 & 22.7 \\
\hline $\begin{array}{l}\text { Previous deliveries without an adverse } \\
\text { pregnancy outcome }\end{array}$ & 31.2 & 29.5 & 32.3 & 50.5 \\
\hline Previous adverse pregnancy outcome ${ }^{a}$ & 27.8 & 28.9 & 30.1 & 26.8 \\
\hline Menstrual irregularity & 9.5 & 11.0 & 9.9 & 5.5 \\
\hline Regular smoking & 10.7 & 15.7 & 13.9 & 13.7 \\
\hline Alcohol intake & 47.2 & 42.2 & 44.9 & 25.3 \\
\hline Intake of drugs in the first trimester ${ }^{b}$ & 27.0 & 27.7 & 28.4 & 27.2 \\
\hline Common cold or fever in the first trimester & 16.7 & 16.0 & 10.7 & 13.0 \\
\hline
\end{tabular}

a Previous induced abortion, miscarriage, preterm delivery, malformed child, or stillbirth.

b Vitamins and tonics excluded.

series, and mutually consistent maximum likelihood estimates of odds ratios for several exposure levels were computed (16).

In the restricted study group, from which the mothers in agricultural work had been excluded, the case and noncase series were not correlated with respect to physical work load, and therefore, to gain efficiency $(17,18)$, the restricted analyses were performed for unmatched series. The confidence intervals for the crude odds ratios were calculated with the modified Cornfield method $(19,20)$. The adjusted odds ratio estimates and their confidence intervals were calculated from the results of unconditional logistic regression analyses which were executed with the SAS software system (21). The independent variables were entered in the models as binary codes or with the use of category indicators.

\section{Birthweight and course of pregnancy}

The effects on birthweight and course of pregnancy were determined from the noncase mothers' experience. This approach has been described in more detail elsewhere $(22,23)$. The Register questionnaires and the records of the maternity health care center were used to obtain information on the noncase mothers' pregnancies. The mother was asked in the Register interview if she had had a threatened abortion during her pregnancy; for $88 \%$ of the mothers who had experienced vaginal bleeding the symptoms had occurred in the first or second trimester. An increase of at least $20 \mathrm{~mm} \mathrm{Hg}(3 \mathrm{kPa})$ in the mean arterial blood pressure between the mother's first visit to the maternity health care center and her last visit before delivery was considered a sign of pregnancy-induced hypertension (24). The length of gestation was calculated from the first day of the last normal menstrual period. We analyzed the occurrence of pregnancies that were shorter than $280 \mathrm{~d}$ because the noncase series was too small to permit a study of preterm birth. The reference value for the definition of a small baby for his or her gestational age was the tenth percentile birthweight of the babies of the same sex in the same gestational age group born to mothers in work that included only light activities when short-term physical load was considered. When mean physical load was examined, the reference birthweight was obtained from the group in sedentary work. 
The applied gestational age groups were $<37$ weeks, $37-39$ weeks, $40-41$ weeks, and $\geq 42$ weeks. (For more details on these outcomes, see references 22,23 , 25.)

In all, 1042 of the noncase mothers with a singleton birth had worked throughout most of their pregnancy and had descriptions of their work that enabled the assessment of the physical load by trimesters of pregnancy. Of these mothers, $952(91 \%)$ had had a physical load that was approximately similar during their entire period of work during pregnancy. Respectively, 140 mothers had been employed on a temporary basis during their pregnancy. A total of 270 women had not worked during pregnancy, 15 of the working women did not have singleton births, and for eight mothers the physical work load could not be assessed. A total of 1152 mothers $(97 \%)$ had worked in the first trimester, $1141(97 \%)$ in the second, and $1035(88 \%)$ in the third. When the occurrence of threatened abortion was studied, all the mothers who had had a singleton birth and who had worked were included in the analyses, but, when other aspects of pregnancy were examined, only mothers who had worked throughout most of their pregnancy were considered. (For more information on the mothers who had worked temporarily, see reference 25.) The mothers' socioeconomic class and the features of their work were controlled in the same manner as in the analyses on malformations.

The work of 564 mothers in the first trimester had included only physically light activities, 338 mothers had work that included activities with a moderate physical load, and 250 mothers had been in jobs in which some tasks had had a high physical load. According to the weighted activity score 647 mothers had done sedentary work, 279 had done standing work, 98 had done work which included walking, and 128 had done work with a moderate mean physical load in the first trimester.

For threatened abortion we adjusted for maternal age, parity, outcome of previous pregnancies, history of menstrual irregularity, intake of drugs, alcohol consumption, and smoking. For pregnancy-induced hypertension maternal age, parity, outcome of previous pregnancies, alcohol intake, and smoking were adjusted for. The models for length of gestation included the covariates maternal age, parity, outcome of previous pregnancies, history of menstrual irregularity, alcohol intake, and smoking. When studying the occurrence of babies small for their gestational age, we controlled for maternal age, parity, outcome of previous pregnancies, maternal prepregnancy weight, alcohol intake, and smoking.

The estimates and confidence limits for the crude risk ratios were calculated according to the chi-square function procedure of Miettinen \& Nurminen (20). To test for trend in the proportions according to the ordinal level of physical load, we used the chi-square statistic of Armitage (26). The estimates for the adjusted risk ratios were calculated from the results of binomial regression analyses executed with the generalized linear interactive modeling (GLIM) program and the macros written by Wacholder (27). Independent variables were defined, and analyses were performed that corresponded to the procedures that were used to study malformations.

\section{Results}

\section{Malformations}

The crude odds ratio of all birth defects pooled for work with a mean physical load at the moderate level in the first trimester was 1.5 with a $95 \%$ confidence interval $(95 \% \mathrm{CI})$ of $1.1-2.0$, for work which involved walking the odds ratio was $0.9(95 \% \mathrm{CI}$ $0.6-1.3)$, and for standing work it was $1.1(95 \% \mathrm{Cl}$ $0.9-1.4)$, as compared with sedentary work. The crude overall odds ratio for work which occasionally included activities with a high physical load was 1.1 (95 \% CI 0.8-1.4), and for work that involved activities with a moderate physical load the odds ratio was 1.2 (95\% CI 0.9-1.5), as compared with work which included only physically light tasks.

When the analyses were restricted to nonagricultural workers in the two socioeconomic categories of lowerlevel employees with administrative and clerical occupations and manual workers, the mothers with a moderate mean physical load showed increased crude and adjusted odds ratios for defects of the central nervous system (table 7). Similarly, for high short-term physical load, the crude and adjusted odds ratios for defects of the central nervous system were raised (adjusted odds ratio $1.6,95 \%$ CI $1.1-2.4$ ) when compared with work that had included only physically light activities. For moderate mean physical load the crude and adjusted odds ratios for orofacial clefts were also slightly elevated (table 7), but this association was not seen for short-term physical load. The odds ratio point estimates of cardiovascular defects were somewhat raised for both the mean and short-term physical load. The occurrence of skeletal defects was not associated with physical work load.

\section{Vaginal bleeding (threatened abortion)}

There was no relation between an increase in mean physical load and the occurrence of vaginal bleeding, but the crude risk ratio was $1.6(95 \%$ CI $1.1-2.3)$ for all the mothers who, in the first trimester, had been in work that involved standing as compared with mothers in sedentary work. The restriction of the subjects to nonagricultural workers in the two socioeconomic categories of lower-level employees with administrative and clerical occupations and manual workers yielded similar results (table 8). The mothers whose work had occasionally included activities of high short- 
term physical load in the first trimester of pregnancy had had slightly more vaginal bleeding than those whose work had involved only physically light tasks (table 8).

\section{Pregnancy-induced hypertension}

An increase in the mean physical load of the third trimester was not associated with pregnancy-induced hypertension. The crude risk ratio was 1.2 (95\% CI $0.6-2.3$ ) for work with a moderate mean load in the third trimester as compared with sedentary work. Similarly, the mean physical load in the second trimester was not related to pregnancy-induced hypertension. When the data were restricted to the nonagricultural workers in the two socioeconomic classes of lower-level employees with administrative and clerical occupations and manual workers, the adjusted risk ratio for moder- ate mean physical load in the third trimester was 1.1 (0.4-3.2) as compared with sedentary work in the same trimester. (See table 9.)

Among all the mothers who worked in the third trimester, those who had done work that occasionally included activities with a high short-term physical load had had more pregnancy-induced hypertension than the mothers whose occupational tasks had all been physically light (crude risk ratio 1.6, $95 \%$ CI 1.0-2.7). Similarly, work in tasks with a high shortterm physical load in the second trimester involved a slightly elevated risk of pregnancy-induced hypertension (risk ratio $1.5,95 \%$ CI $0.9-2.4$ ). When the data were restricted to the nonagricultural workers in the socioeconomic categories of lower-level employees with administrative and clerical occupations and manual workers, the adjusted risk ratio for work that occasionally included activities with a high physical load

Table 7. Birth defects according to the mean physical load in the first trimester of pregnancy among the nonagricultural workers in the socioeconomic classes of lower-level employees with administrative and clerical occupations and manual workers. $(95 \% \mathrm{Cl}=95 \%$ confidence interval)

\begin{tabular}{|c|c|c|c|c|c|c|c|c|c|c|}
\hline \multirow{2}{*}{ Birth defect } & \multirow{2}{*}{$\begin{array}{l}\text { Sedentary } \\
\text { work } \\
\text { (N) }\end{array}$} & \multicolumn{3}{|c|}{ Standing work } & \multicolumn{3}{|c|}{$\begin{array}{l}\text { Work involving } \\
\text { walking }\end{array}$} & \multicolumn{3}{|c|}{$\begin{array}{c}\text { Work with a moderate } \\
\text { physical load }\end{array}$} \\
\hline & & $\mathrm{N}$ & $\begin{array}{l}\text { Odds } \\
\text { ratio }\end{array}$ & $95 \% \mathrm{Cl}$ & $\mathrm{N}$ & $\begin{array}{l}\text { Odds } \\
\text { ratio }\end{array}$ & $95 \% \mathrm{Cl}$ & $\mathrm{N}$ & $\begin{array}{l}\text { Odds } \\
\text { ratio }\end{array}$ & $95 \% \mathrm{Cl}$ \\
\hline $\begin{array}{l}\text { Central nervous } \\
\text { system defects }\end{array}$ & 93 & 72 & $\begin{array}{l}1.5 \\
1.7\end{array}$ & $\begin{array}{l}1.1-2.2 \\
1.2-2.5\end{array}$ & 19 & $\begin{array}{l}1.2 \\
1.4\end{array}$ & $\begin{array}{l}0.7-2.1 \\
0.8-2.5\end{array}$ & 25 & $\begin{array}{l}2.4 \\
3.0\end{array}$ & $\begin{array}{l}1.4-4.0 \\
1.6-5.5^{b}\end{array}$ \\
\hline Orofacial clefts & 181 & 104 & $\begin{array}{l}1.1 \\
1.0\end{array}$ & $\begin{array}{l}0.9-1.5 \\
0.8-1.4\end{array}$ & 31 & $\begin{array}{l}1.0 \\
1.3\end{array}$ & $\begin{array}{l}0.7-1.6 \\
0.8-2.1\end{array}$ & 33 & $\begin{array}{l}1.6 \\
1.8\end{array}$ & $\begin{array}{l}1.0-2.5 \\
1.1-3.0\end{array}$ \\
\hline Skeletal defects & 137 & 67 & $\begin{array}{l}1.0 \\
0.9\end{array}$ & $\begin{array}{l}0.7-1.4 \\
0.6-1.3\end{array}$ & 16 & $\begin{array}{l}0.7 \\
0.7\end{array}$ & $\begin{array}{l}0.4-1.2 \\
0.4-1.3\end{array}$ & 15 & $\begin{array}{l}1.0 \\
0.9\end{array}$ & $\begin{array}{l}0.5-1.7 \\
0.5-1.8\end{array}$ \\
\hline $\begin{array}{l}\text { Cardiovascular } \\
\text { defects }\end{array}$ & 55 & 34 & $\begin{array}{l}1.2 \\
1.5\end{array}$ & $\begin{array}{l}0.8-1.9 \\
0.9-2.4\end{array}$ & 15 & $\begin{array}{l}1.7 \\
2.0\end{array}$ & $\begin{array}{l}0.9-3.0 \\
1.0-3.8\end{array}$ & 9 & $\begin{array}{l}1.4 \\
1.7\end{array}$ & $\begin{array}{l}0.7-3.0 \\
0.7-4.0\end{array}$ \\
\hline Noncases & 522 & 261 & & & 86 & & & 59 & & \\
\hline
\end{tabular}

a Upper figure = crude odds ratio, lower figure = adjusted odds ratio in contrast to sedentary work.

b Estimates for other variables connected with work obtained from the model: manual worker (0.8, 95 \% Cl $0.5-1.2)$, temporary work $(1.2,95 \% \mathrm{Cl} 0.7-2.0)$, shift work $(0.9,95 \% \mathrm{Cl} 0.6-1.4)$, noise exposure $(0.7,95 \% \mathrm{Cl} 0.4-1.3)$, solvent exposure $(2.1,95 \% \mathrm{Cl} 1.1-4.1)$, long work week $(0.7,95 \% \mathrm{Cl} 0.4-1.6)$. In addition, the model included the maternal characteristics listed in the Subjects and Methods section.

Table 8. Vaginal bleeding (threatened abortion) and physical work load in the first trimester of pregnancy among the nonagricultural workers in the socioeconomic classes of lower-level employees with administrative and clerical occupations and manual workers.

\begin{tabular}{|c|c|c|c|c|c|c|}
\hline & \multirow{2}{*}{$\begin{array}{l}\text { Number of } \\
\text { mothers }^{a}\end{array}$} & \multicolumn{2}{|c|}{ Vaginal bleeding } & \multirow{2}{*}{$\begin{array}{l}\text { Crude risk } \\
\text { ratio }^{b}\end{array}$} & \multirow{2}{*}{\multicolumn{2}{|c|}{$\begin{array}{l}\text { Adjusted risk } \\
\text { ratiob }^{b}\end{array}$}} \\
\hline & & $N$ & $\%$ & & & \\
\hline \multicolumn{7}{|l|}{ Mean physical load } \\
\hline $\begin{array}{l}\text { Sedentary work } \\
\text { Standing work } \\
\text { Work involving walking } \\
\text { Work with a moderate physical load }\end{array}$ & $\begin{array}{r}516 \\
259 \\
84 \\
58\end{array}$ & $\begin{array}{r}43 \\
33 \\
9 \\
6\end{array}$ & $\begin{array}{r}8.3 \\
12.7 \\
10.7 \\
10.3\end{array}$ & $\begin{array}{ll}1.5 & (1.0-2.3) \\
1.3 & (0.6-2.5) \\
1.2 & (0.6-2.6)\end{array}$ & $\begin{array}{l}1.6 \\
1.1 \\
1.0\end{array}$ & $\begin{array}{l}(1.0-2.5) \\
(0.5-2.3) \\
(0.5-2.3)\end{array}$ \\
\hline \multicolumn{7}{|l|}{ Short-term physical load } \\
\hline $\begin{array}{l}\text { Light } \\
\text { Moderate } \\
\text { High }\end{array}$ & $\begin{array}{l}456 \\
270 \\
191\end{array}$ & $\begin{array}{l}38 \\
30 \\
23\end{array}$ & $\begin{array}{l}8.3 \\
11.1 \\
12.0^{\mathrm{C}}\end{array}$ & $\begin{array}{ll}1.3 & (0.8-2.1) \\
1.4 & (0.9-2.3)\end{array}$ & $\begin{array}{l}1.2 \\
1.4\end{array}$ & $\begin{array}{l}(0.7-1.9) \\
(0.8-2.3)\end{array}$ \\
\hline
\end{tabular}

a There were four mothers with missing data on the symptoms.

b $95 \%$ confidence interval in parentheses.

c Test for trend in proportions: $X^{2}=2.5, P=0.1$. 
Table 9. Pregnancy-induced hypertension and physical work load in the third trimester of pregnancy among the nonagricultural workers in the socioeconomic classes of lower-level employees with administrative and clerical occupations and manual workers.

\begin{tabular}{|c|c|c|c|c|c|c|c|}
\hline & \multirow[t]{2}{*}{$\begin{array}{l}\text { Number of } \\
\text { mothers }\end{array}$} & \multicolumn{2}{|c|}{$\begin{array}{l}\text { Pregnancy-induced } \\
\text { hypertension }\end{array}$} & \multirow{2}{*}{\multicolumn{2}{|c|}{$\begin{array}{l}\text { Crude risk } \\
\text { ratio }^{b}\end{array}$}} & \multirow{2}{*}{\multicolumn{2}{|c|}{$\begin{array}{l}\text { Adjusted risk } \\
\text { ratio }^{b}\end{array}$}} \\
\hline & & $\mathbf{N}$ & $\%$ & & & & \\
\hline \multicolumn{8}{|l|}{ Mean physical load } \\
\hline $\begin{array}{l}\text { Sedentary work } \\
\text { Standing work } \\
\text { Work involving walking } \\
\text { Work with a moderate physical load }\end{array}$ & $\begin{array}{r}487 \\
200 \\
69 \\
42\end{array}$ & $\begin{array}{r}33 \\
17 \\
5 \\
4\end{array}$ & $\begin{array}{l}6.8 \\
8.5 \\
7.2 \\
9.5\end{array}$ & $\begin{array}{l}1.3 \\
1.1 \\
1.4\end{array}$ & $\begin{array}{l}(0.7-2.2) \\
(0.4-2.5) \\
(0.5-3.5)\end{array}$ & $\begin{array}{l}1.1 \\
1.0 \\
1.1\end{array}$ & $\begin{array}{l}(0.6-2.0) \\
(0.4-2.6) \\
(0.4-3.2)\end{array}$ \\
\hline \multicolumn{8}{|l|}{ Short-term physical load } \\
\hline $\begin{array}{l}\text { Light } \\
\text { Moderate } \\
\text { High }\end{array}$ & $\begin{array}{l}433 \\
216 \\
149\end{array}$ & $\begin{array}{l}25 \\
18 \\
16\end{array}$ & $\begin{array}{r}5.8 \\
8.3 \\
10.7^{c}\end{array}$ & $\begin{array}{l}1.4 \\
1.9\end{array}$ & $\begin{array}{l}(0.8-2.6) \\
(1.0-3.3)\end{array}$ & $\begin{array}{l}1.4 \\
2.1\end{array}$ & $\begin{array}{l}(0.7-2.5) \\
(1.1-3.8)\end{array}$ \\
\hline
\end{tabular}

a There were three mothers with missing data on blood pressure.

b $95 \%$ confidence interval in parentheses.

c Test for trend in proportions: $\mathrm{X}^{2}=4.4, \mathrm{P}=0.04$.

Table 10. Length of gestation and physical work load in the third trimester of pregnancy among all the mothers who worked during most of their pregnancy.

\begin{tabular}{|c|c|c|c|c|c|c|c|c|c|}
\hline & \multirow{3}{*}{$\begin{array}{l}\text { Number of } \\
\text { mothers }^{a}\end{array}$} & \multicolumn{8}{|c|}{ Length of gestation (weeks) } \\
\hline & & \multicolumn{2}{|c|}{$<37$} & \multicolumn{2}{|c|}{$37-39$} & \multicolumn{2}{|c|}{$40-41$} & \multicolumn{2}{|c|}{$\geq 42$} \\
\hline & & $\mathrm{N}$ & $\%$ & $N$ & $\%$ & $\mathrm{~N}$ & $\%$ & $N$ & $\%$ \\
\hline \multicolumn{10}{|l|}{ Mean physical load } \\
\hline $\begin{array}{l}\text { Sedentary work } \\
\text { Standing work } \\
\text { Work involving walking } \\
\text { Work with a moderate physical load }\end{array}$ & $\begin{array}{r}579 \\
207 \\
74 \\
96\end{array}$ & $\begin{array}{r}16 \\
3 \\
1 \\
1\end{array}$ & $\begin{array}{l}2.8 \\
1.5 \\
1.3 \\
1.0\end{array}$ & $\begin{array}{r}216 \\
87 \\
27 \\
56\end{array}$ & $\begin{array}{l}37.3 \\
42.0 \\
36.5 \\
58.3\end{array}$ & $\begin{array}{r}307 \\
100 \\
37 \\
37\end{array}$ & $\begin{array}{l}53.0 \\
48.3 \\
50.0 \\
38.6\end{array}$ & $\begin{array}{r}40 \\
17 \\
9 \\
2\end{array}$ & $\begin{array}{r}6.9 \\
8.2 \\
12.2 \\
2.1\end{array}$ \\
\hline \multicolumn{10}{|l|}{ Short-term physical load } \\
\hline $\begin{array}{l}\text { Light } \\
\text { Moderate } \\
\text { High }\end{array}$ & $\begin{array}{l}514 \\
259 \\
183\end{array}$ & $\begin{array}{r}15 \\
4 \\
2\end{array}$ & $\begin{array}{l}2.9 \\
1.6 \\
1.1\end{array}$ & $\begin{array}{r}188 \\
113 \\
85\end{array}$ & $\begin{array}{l}36.6 \\
43.6 \\
46.4\end{array}$ & $\begin{array}{r}274 \\
123 \\
84\end{array}$ & $\begin{array}{l}53.3 \\
47.5 \\
45.9\end{array}$ & $\begin{array}{l}37 \\
19 \\
12\end{array}$ & $\begin{array}{l}7.2 \\
7.3 \\
6.6\end{array}$ \\
\hline
\end{tabular}

a There were 16 mothers with missing data on the length of gestation.

in the third trimester was $2.1(95 \%$ CI $1.1-3.8)$ as compared with work that involved only physically light tasks. (See table 9.)

\section{Length of gestation and birthweight}

Altogether, $59 \%$ of the mothers with a moderate mean physical load in the third trimester had a gestation that was shorter than $280 \mathrm{~d}$, whereas in sedentary work the corresponding percentage was 40 (crude risk ratio 1.5 , $95 \%$ CI 1.2-1.8; adjusted risk ratio $1.4,95 \% \mathrm{CI}$ 1.1-1.7). In all, for $48 \%$ of the mothers whose shortterm physical load had been high, the length of gestation was less than $280 \mathrm{~d}$, and this percentage was 39 for mothers whose work tasks had all been light (crude risk ratio $1.2,95 \%$ CI 1.0-1.4; adjusted risk ratio $1.2,95 \% \mathrm{CI} 1.0-1.4$ ). Table 10 shows the distributions of length of gestation for mean and short-term physical load. When the study mothers were restricted to nonagricultural workers in the two socioeconomic classes of lower-level employees with administrative and clerical occupations and manual workers, the adjusted risk ratio of shortened length of gestation was
$1.1(95 \%$ CI $0.7-1.6)$ for mean physical load at the moderate level as compared with sedentary work. For high short-term physical load the corresponding adjusted risk ratio was $1.1(95 \% \mathrm{CI} 0.9-1.4)$ as contrasted to work which included only physically light tasks.

Among all the mothers who worked in the third trimester, the tenth percentile birthweight was $2860 \mathrm{~g}$ for the babies born to mothers whose mean physical load had been at the moderate level, whereas the respective birthweight for the group in sedentary work was $3000 \mathrm{~g}$ (table 11). The crude risk ratio for mothers in work with a moderate mean physical load in the third trimester giving birth to babies that were small for their gestational age was $1.3(95 \% \mathrm{CI} 0.7-2.3)$ when they were compared with the mothers in sedentary work, and the corresponding adjusted risk ratio was 1.5 (95\% CI 0.8-2.8). When the study group was restricted to nonagricultural workers in the two socioeconomic classes of lower-level employees with administrative and clerical occupations and manual workers, the mothers with the heaviest physical load according to the mean and short-term level had an excess of small 
babies as compared with the mothers at the lightest level of physical load (table 12). The adjusted risk ratio was $2.4(95 \%$ CI 1.3-4.6) for the mothers with a moderate mean physical load as compared with mothers in sedentary work.

\section{Placental weight}

In all, $5.2 \%$ of the mothers whose mean physical load had been at the moderate level in the third trimester had placentas weighing $400 \mathrm{~g}$ or less as against $3.6 \%$ of the mothers in sedentary work (risk ratio $1.4,95 \%$ CI 0.6-3.6). The corresponding percentages for mothers with high and light short-term physical loads were 4.4 and 3.7 , respectively (risk ratio $1.2,95 \% \mathrm{CI}$ $0.5-2.6)$.

\section{Discussion}

Many of the mothers with the same occupational title had had a very different physical load when assessed from the description of the mother's ordinary workday. In our data, there were only seven mothers whose main activity level had been high or very high. On the other hand, some $20 \%$ of the mothers had worked part of the time at a high or very high level of physical load. (See table 2.) Thus, as assessed with the use of an average of the major and minor levels weighted by the proportion of worktime spent at the level concerned, the group with the physically most loading work in our study had a moderate mean level. Most of the mothers whose short-term physical load had been at a high or very high level had had a heavy load only sporadically. The two heaviest levels of the standardized categories of physical load have suggestive metabolic reference values indicating that the energy expenditure in the body could be around eight to ten times greater than if the person were in a state of complete rest but awake. (See table 1 and reference 13.) The applicability of the basic activity categories and the concerned metabolic reference values have been tested in occupational groups with the use of measurements of heart rate and oxygen consumption (13), but the groups have not included pregnant women. In our study no physiological measurements were taken, nor did we have any data on the mother's physical work capacity. Thus, the assessment of physical load applies to loading factors at work and not to the mother's actual strain. The correspondence of work load with work strain in earlier studies has indicated that the Edholm method can overestimate the work load at lower levels, but the correspondence is good at moderate and high levels (13).

Unexpectedly, mean physical load and the occurrence of central nervous system defects were related in the study data (table 7), and indications of a relation were seen also for short-term physical load. Similarly, the somewhat elevated odds ratios for orofacial clefts and cardiovascular defects were unexpected. (Compare the results presented in reference 6.)

Our study involved the simultaneous assessment of associations between many occupational factors and

Table 11. Birthweight and mother's physical load in the third trimester of pregnancy among all the mothers who worked during most of their pregnancy.

\begin{tabular}{|c|c|c|c|}
\hline & \multirow{2}{*}{$\begin{array}{c}\text { Number of } \\
\text { babies }^{a}\end{array}$} & \multicolumn{2}{|c|}{ Birthweight (g) } \\
\hline & & Median & $\begin{array}{c}\text { Tenth } \\
\text { percentile }\end{array}$ \\
\hline \multicolumn{4}{|l|}{ Mean physical load } \\
\hline $\begin{array}{l}\text { Sedentary work } \\
\text { Standing work } \\
\text { Work involving walking } \\
\text { Work with a moderate }\end{array}$ & $\begin{array}{r}586 \\
212 \\
74\end{array}$ & $\begin{array}{l}3525 \\
3565 \\
3650\end{array}$ & $\begin{array}{l}3000 \\
2940 \\
3130\end{array}$ \\
\hline physical load & 99 & 3470 & 2860 \\
\hline \multicolumn{4}{|l|}{ Short-term physical load } \\
\hline $\begin{array}{l}\text { Light } \\
\text { Moderate } \\
\text { High }\end{array}$ & $\begin{array}{l}520 \\
264 \\
187\end{array}$ & $\begin{array}{l}3520 \\
3565 \\
3600\end{array}$ & $\begin{array}{l}3000 \\
2950 \\
2980\end{array}$ \\
\hline
\end{tabular}

a There was one mother with missing data on the birthweight of the baby.

Table 12. Babies who were small for their gestational age and physical work load in the third trimester of pregnancy among the nonagricultural workers in the socioeconomic classes of lower-level employees with administrative occupations and manual workers.

\begin{tabular}{|c|c|c|c|c|c|c|}
\hline & \multirow{2}{*}{$\begin{array}{l}\text { Total } \\
\text { number of } \\
\text { babies }^{\text {a }}\end{array}$} & \multicolumn{2}{|c|}{$\begin{array}{l}\text { Babies small for } \\
\text { gestational age }\end{array}$} & \multirow{2}{*}{$\begin{array}{l}\text { Grude risk } \\
\text { ratio }^{\text {b }}\end{array}$} & \multirow{2}{*}{\multicolumn{2}{|c|}{$\begin{array}{c}\text { Adjusted risk } \\
\text { ratio }^{b}\end{array}$}} \\
\hline & & $N$ & $\%$ & & & \\
\hline \multicolumn{7}{|l|}{ Mean physical load } \\
\hline $\begin{array}{l}\text { Sedentary work } \\
\text { Standing work } \\
\text { Work involving walking } \\
\text { Work with a moderate physical load }\end{array}$ & $\begin{array}{r}481 \\
195 \\
67 \\
43\end{array}$ & $\begin{array}{r}43 \\
28 \\
6 \\
9\end{array}$ & $\begin{array}{r}8.9 \\
14.4 \\
9.0 \\
20.9\end{array}$ & $\begin{array}{l}(1.0-2.5) \\
(0.4-2.2) \\
(1.2-4.3)\end{array}$ & $\begin{array}{l}1.4 \\
1.0 \\
2.4\end{array}$ & $\begin{array}{l}(0.9-2.3) \\
(0.4-2.3) \\
(1.3-4.6)\end{array}$ \\
\hline \multicolumn{7}{|l|}{ Short-term physical load } \\
\hline $\begin{array}{l}\text { Light } \\
\text { Moderate } \\
\text { High }\end{array}$ & $\begin{array}{l}427 \\
214 \\
145\end{array}$ & $\begin{array}{l}37 \\
23 \\
21\end{array}$ & $\begin{array}{l}8.7 \\
10.7 \\
14.5^{c}\end{array}$ & $\begin{array}{l}(0.8-2.0) \\
(1.0-2.7)\end{array}$ & $\begin{array}{l}1.1 \\
1.8\end{array}$ & $\begin{array}{l}(0.6-1.8) \\
(1.1-2.9)\end{array}$ \\
\hline
\end{tabular}

a There were 16 mothers for whom the size for gestational age could not be defined.

b $95 \%$ confidence interval in parentheses.

c Test for trend in proportions: $X^{2}=3.9, P=0.05$. 
four groups of structural birth defects from the same data. The study was not designed to test certain specific hypotheses, and thus caution is needed in the interpretation of the observed relations. Specific mechanisms of teratogenesis are poorly understood, and the effects of any single factor are obscured by other variables. Most of the mothers with a moderate mean physical load during work were manual workers (table 4), and, moreover, half of them had worked in agriculture as against only a small proportion in the physically lighter work load category (table 5). Therefore further analyses were restricted to nonagricultural workers in the two socioeconomic classes of lower-level employees with administrative and clerical occupations and manual workers. In addition, we controlled some aspects of work and also maternal background characteristics in the analyses. However it is possible that the observed relations were attributable to some unrecognized confounders, and then physical load would be a surrogate for something else. Besides, biases in maternal recall (during the interviews or in the assessment of exposure) are possible when information is acquired retrospectively. The mothers of the case-noncase pairs were usually interviewed at the same time after delivery, but especially the mothers of the babies with central nervous system defects gave birth earlier than the noncase mothers. Their length of gestation averaged about three weeks less; thus, at the interview, the time since the beginning of pregnancy was usually shorter for these case mothers than for the noncase mothers. Whether this phenomenon might cause differences in recalling the course of an ordinary workday in the first trimester of pregnancy remains obscure. The trained interviewers, who recorded the mothers' free-form workday descriptions, were unaware of any specific hypotheses that might be tested, and they gathered information on several factors connected with work. The assessment of physical work load was done by an expert on the basis of the workday description, and she did not know the course or outcome of the pregnancy. Therefore at least the presence of the two last biases seems unlikely. However, the prior probability that physical load could induce birth defects was low, and thus we would like to emphasize the possibility that our findings are chance or proxy associations. Moreover, concerning central nervous system defects, the possibility of differences in maternal recall could not clearly be ruled out.

In our study data, there was no relation between an increase in mean physical load in the first trimester and the occurrence of threatened abortion (vaginal bleeding); yet standing work was associated with a 1.5-fold risk (table 8 ). The mothers whose short-term physical load had been high also showed indications of an elevated risk. It should be noted that some $40 \%$ of the mothers in standing work had occasionally had tasks in their work that involved a high short-term physical load (table 3).
The mothers whose short-term physical load in the second or third trimester had been high had experienced more pregnancy-induced hypertension than the mothers in work that included only light activities (table 9). Nevertheless, an increasing mean physical load was not associated with this outcome. There was variability in the time of the first blood pressure measurements, and women with pregnancy-induced hypertension who had registered late at the maternity health care center might have been lost. However, a connection between physical work load and the time of the first visit that could have biased the observed results does not seem plausible because of the comprehensive maternity care system in Finland. (For more information on this subject, see reference 25.)

Among all the mothers who had worked throughout most of their pregnancy, physical load appeared to shorten the gestation, but the restricted analyses showed no such associations. Moreover, our study was too small to permit an evaluation of preterm delivery.

Indications of a relation between physical activity in the third trimester and reduced prenatal growth were seen for both mean and short-term physical load. The excess of small babies among the mothers with a moderate mean physical load or a high short-term load could be seen especially when the analyses were restricted to nonagricultural workers in the two socioeconomic classes of lower-level employees with administrative and clerical occupations and manual workers (table 12), but in the more heterogeneous data the excess was smaller. Furthermore, for mothers in standing work, a moderate risk of giving birth to small babies could not be ruled out in light of the obtained results.

The original objective of our study was to explore possible factors of teratogenecity in the work environment, and, later, the available noncase mothers' experience was used to study outcomes of pregnancy other than malformations. Related to the obtained results, the issue of possible chance or proxy findings is similarly a cause for concern as in evaluations of associations linked to birth defects. A reduction in birthweight has been considered one of the most likely possible effects of physical load on the fetus (1). Some epidemiologic studies on maternal work conditions and pregnancy have reported suggestive findings concerning physical load and reduced birthweight (2, 28-31). A higher risk of spontaneous abortion and shortened gestation has also been reported for physically demanding jobs $(2,30-34)$, but in other studies no relation was observed between preterm birth and physical strain $(5,35)$.

In the aforementioned studies, the definitions of physical load have included physical effort, heavy lifting, and standing, and a persistent difficulty has been, and is, the categorization of women according to varying physical work demands (36). Consequently, the interpretation of the concerned exposure is not evident, and the comparison of results from different studies 
is cumbersome. To increase the complexity, physical work loads typically occur in environments which contain chemical and other types of occupational exposures that are also potentially harmful during pregnancy. It is also possible that different kinds of physical load (static versus dynamic, long-term versus shortterm), if indeed harmful to the fetus or pregnancy, might not have similar effects upon the different outcome variables included in different studies.

Still, the prior probability of a possible relation between physical load and reduced birthweight or an adverse course of pregnancy was higher than for malformations. Our results gave some indications of possible effects, and our findings also suggested that prolonged and short-term physical load could have different consequences. However, the effects of the increased metabolic demands and other loading aspects of physical activity on the course and outcome of pregnancy need to be studied further.

\section{Acknowledgments}

We thank Ms R Vesanto-Paavola and Ms T Suomela for their skillful technical assistance and the Finnish Work Environment Fund for its financial support.

\section{References}

1. Lotgering $\mathbf{F}$, Gilbert $\mathrm{R}$, Longo $\mathbf{L}$. The interactions of exercise and pregnancy: a review. Am J Obstet Gynecol 1984;149:560-8.

2. Armstrong BG, Nolin AD, McDonald AD. Work in pregnancy and birth weight for gestational age. $\mathrm{Br} \mathrm{J}$ Ind Med 1989;46:196-9.

3. Goulet L, Thériault G. Association between spontaneous abortion and ergonomic factors: a literature review of the epidemiologic evidence. Scand J Work Environ Health 1987;13:399-403.

4. McDonald AD. Editorial: work and pregnancy. $\mathrm{Br} \mathrm{J}$ Ind Med 1988;45:577-80.

5. Berkowitz G, Kelsey J, Holford T, Berkowitz R. Physical activity and the risk of spontaneous preterm delivery. J Reprod Med 1983;28:581-8.

6. McDonald AD, McDonald JC, Armstrong B, et al. Congenital defects and work in pregnancy. $\mathrm{Br} \mathrm{J}$ Ind Med 1988;45:581-8.

7. Holmberg PC, Kurppa K. An epidemiologic approach to the study of possible teratogenic effects of chemical and physical environments. Scand $J$ Work Environ Health 1982;8(suppl 1):89-91.

8. Kurppa K, Holmberg PC, Hernberg S, Rantala K, Riala R, Nurminen T. Screening for occupational exposures and congenital malformations: preliminary results from a nationwide case-referent study. Scand J Work Environ Health 1983;9:89-93.

9. Kurppa K, Rantala K, Nurminen T, Holmberg PC, Starck J. Noise exposure during pregnancy and selected structural malformations in infants. Scand J Work Environ Health 1989;15:111-6.

10. Saxén L. Twenty years of study of the etiology of congenital malformations in Finland. In: Kalter H, ed. Issues and reviews in teratology; vol 1. New York, NY: Plenum Publishing Corporation, 1983:73-110.

11. Holmberg PC, Nurminen M. Congenital defects of the central nervous system and occupational factors during pregnancy: a case-referent study. Am J Ind Med 1980; $1: 167-76$.

12. Edholm OG. The assessment of habitual activity. In: Evang K, Lange Andersen K, ed. Physical activity in health and disease. Oslo: Universitetsforlaget, 1966: 187-97.

13. Ilmarinen J, Knauth $P$, Klimmer F, Rutenfranz J. The applicability of the Edholm scale for activity studies in industry. Ergonomics 1979; 22:369-76.

14. Central Statistical Office of Finland. Ammattiluokitus: yrkesklassificering: classification of occupations 1980. Helsinki: Central Statistical Office of Finland, 1981.

15. American Conference of Governmental Industrial Hygienists. Threshold limit values for chemical substances in workroom air adopted by the American Conference of Governmental Industrial Hygienists for 1981. Cincinnati, $\mathrm{OH}$ : American Conference of Governmental Industrial Hygienists, 1981.

16. Pike MC, Casagrande J, Smith PG. Statistical analysis of individually matched case control studies in epidemiology: factor under study a discrete variable taking multiple values. Br J Prev Soc Med 1975;29:196-201.

17. Miettinen OS. The matched pairs design in the case of all-or-none responses. Biometrics 1968;24:339-52.

18. Rothman KJ. Modern epidemiology. Boston, MA: Little, Brown and Company, 1986.

19. Cornfield J. A statistical problem arising from retrospective studies. In: Neyman J, ed. Proceedings of the third Berkeley symposium on mathematical statistics and probability. Berkeley/Los Angeles, CA: University of California Press, 1956;4:135-48.

20. Miettinen $\mathrm{O}$, Nurminen M. Comparative analysis of two rates. Stat Med 1985;4:213-26.

21. SAS Institute Inc. SAS user's guide: statistics. 5th ed. Cary, NC: SAS Institute Inc, 1985.

22. Nurminen T, Kurppa K. Office employment, work with video display terminals, and course of pregnancy: reference mothers' experience from a Finnish case-referent study of birth defects. Scand J Work Environ Health 1988;14:293-8.

23. Nurminen T, Kurppa K. Authors' reply: on using the reference subjects' experience of a case-referent study for purposes other than the original one [Letter to the editor]. Scand J Work Environ Health 1989;15:156-8.

24. Anderson GD, Sibai BM. Hypertension in pregnancy. In: Gabbe SG, Niebyl JR, Simpson JL, ed. Obstetrics: normal and problem pregnancies. New York, NY: Churchill Livingstone Inc, 1986:819-63.

25. Nurminen T, Kurppa K. Occupational noise exposure and course of pregnancy. Scand J Work Environ Health 1989;15:117-24.

26. Armitage $P$. Tests for linear trends in proportions and frequencies. Biometrics 1955;11:375-86.

27. Wacholder $\mathbf{S}$. Binomial regression in GLIM: estimating risk ratios and risk differences. Am J Epidemiol 1986; 123:174-84.

28. Tafari N, Naeye RL, Gobezie A. Effects of maternal undernutrition and heavy physical work during pregnancy on birth weight. Br J Obstet Gynaecol 1980;87: 222-6.

29. Naeye RL, Peters EC. Working during pregnancy: effects on the fetus. Pediatrics 1982;69:724-7.

30. Saurel-Cubizolles MJ, Kaminski M. Pregnant women's working conditions and their changes during pregnancy: a national study in France. $\mathrm{Br}$ J Ind Med 1987;44: 236-43.

31. McDonald AD, McDonald JC, Armstrong B, Cherry $\mathrm{NM}$, Nolin AD, Robert D. Prematurity and work in pregnancy. Br J Ind Med 1988;45:56-62.

32. Taskinen H, Lindbohm M-L, Hemminki K. Spontaneous abortions among women working in the pharmaceutical industry. Br J Ind Med 1986;43:199-205.

33. McDonald AD, McDonald JC, Armstrong B, et al. Fe- 
tal death and work in pregnancy. Br J Ind Med 1988; 45:148-57.

34. Mamelle N, Laumon B, Lazar P. Prematurity and occupational activity during pregnancy. Am $\mathrm{J}$ Epidemiol 1984;119:309-22.

35. Mamelle N, Munoz F. Occupational working conditions and preterm birth: a reliable scoring system. Am $\mathbf{J}$
Epidemiol 1987;126:150-2.

36. Punnet L, Marbury M. Re: occupational working conditions and preterm birth: a reliable scoring system [Letter to the editor]. Am J Epidemiol 1989;129:451.

Received for publication: 5 July 1989 